\title{
DIREITOS DOS MAIS E MENOS HUMANOS*
}

\section{Claudia Fonseca}

\author{
Universidade Federal do Rio Grande do Sul - Brasil \\ Andrea Cardarello** \\ Université de Montréal - Canadá
}

\begin{abstract}
Resumo: A noção de direitos humanos em sua forma abstrata e descontextualizada pouco significa. Como esta noção é traduzida na prática - e suas conseqüências particulares - depende de relações de poder forjadas em contextos históricos específicos e expressas em categorias semânticas precisas. Depois de considerar como certas categorias são eleitas como alvo merecedor de campanhas em defesa de direitos humanos, concentramo-nos na análise de programas para a institucionalização de crianças $e$ adolescentes na FEBEM-RS, tentando ver como certos processos desencadeados pela legislação progressista acabam produzindo efeitos inesperados. Finalmente, situamos a "infância" como um discurso entre outros que mobilizam campanhas de direitos humanos. Ao atentar para a maneira como uma categoria é priorizada em detrimento de outras, desvendamos lutas simbólicas e critérios particulares que determinam - na reivindicação de direitos - quem é mais, e quem é menos, humano.
\end{abstract}

Palavras-chave: adolescentes infratores, direitos humanos, grupos populares, infância.

Abstract: The notion of human rights means very little in abstract and decontextualized form. How this notion is translated into practice - and the particular consequences of this process - depends on power relations forged in specific historical contexts and expressed in precise semantic categories. After considering how certain categories are elected as privileged targets of rights campaigns, we concentrate efforts on the analysis of programs for the institutionalization of children and adolescents in the state network of reform schools (Rio Grande do Sul), calling attention to the way in which measures promoted by the new progressive legislation do not always

\footnotetext{
* Agradecemos aos participantes da FINA (Frente Inter-disciplinar de Antropologia - PPGAS/UFRGS) e, em particular, a Pablo Semán pelas valiosas sugestões.

** Doutoranda em Antropologia.
} 
produce the desired results. Finally, we situate "childhood" as one discourse among many used to mobilize human rights campaigns. Looking at the way one category is privileged in detriment to others, we detect how particular criteria are used to determine - in the fight for rights - who is "more" and who is "lesshuman".

Keywords: childhood, human rights, juvenile offenders, working-class groups.

Após muitos anos de debate entre militantes dos movimentos sociais, parlamentares e outros membros da sociedade civil, o Brasil teve uma nova Constituição aprovada em 1988. Fiel às tradições do direito romano e inspirado em debates internacionais sobre direitos humanos, o documento reflete altos ideais para uma sociedade ideal. ${ }^{1}$ pede a demarcação imediata das terras indígenas, bem como o reconhecimento dos direitos territoriais dos descendentes de escravos fugitivos; proclama direitos específicos para as mulheres, proteção para os idosos, e respeito ao meio-ambiente. Numa ramificação subseqüente - Estatuto da Criança e do Adolescente (ECA, 1990) - foram reafirmadas disposições já presentes na Constituição quanto ao direito das crianças a escola, família, alimento e lazer. Se esse tipo de legislação é ou não a maneira mais eficaz para alcançar os louváveis objetivos de seus autores não está nada claro.

Por um lado, temos figuras de destaque confessando que, embora a Constituição contenha com certeza muitas idéias excelentes, todo mundo sabe que o país não possui meios para pô-las em prática (ver Comparato, 1998). Por outro lado, temos a reificação de certas categorias sociais - índios, descendentes de escravos fugitivos, mulheres, crianças - perfeitas para alimentar associações filantrópicas e ONGs, denominadas agora de "Terceiro Setor" (Fernandes, 1994). Muito já foi escrito sobre as trapaças e os simulacros de realidade criados pelos benfeitores de grupos oprimidos. $\mathrm{O}$ "índio hiper-real" entronizado por muitas ONGs parece que tem pouco a ver com os impertinentes nativos da vida real, que fazem alianças com multinacionais ou trocam suas terras por bugigangas do consumismo selvagem (Ramos, 1991). A mesma coisa pode ser dita facilmente em relação à folclorização dos quilombolas ou ao tratamento publicitário dos meninos de rua. ${ }^{2}$ Que vantagens tiram esses grupos "subalternos" dessas embalagens mediáticas é uma questão ainda a ser respondida.

\footnotetext{
1 Sobre a importância de "legislação simbólica", ver Vianna (1996).

2 Sobre quilombolas. ver Leite, nesse volume.
} 
O inegável é que eles ocupam um espaço considerável no rateio do interesse público e nas agendas políticas dirigidas à diminuição das injustiças sociais.

Nossa reflexão parte dessas imagens e sua importância enquanto componente básico dos processos de cidadania. Seguindo uma escola de pensamento que vê o simbólico e o político como indissociáveis, sublinhamos a importância dos sistemas de classificação embutidos na linguagem que usamos para descrever (e apreender) a realidade. Levantamos questões sobre a ação de indivíduos inquestionavelmente bem-intencionados que encontram-se embrenhados em determinadas estruturas de significação que não correspondem necessariamente à realidade. Em outras palavras, neste trabalho, procuramos analisar a questão de direitos humanos em termos de "processos discursivos epistemologias, instituições e práticas - que produzem os sujeitos políticos" e informam seus alvos privilegiados de ação ${ }^{3}$ (Scott, 1998, p. 35).

Ao longo desta reflexão corre a premissa de que os direitos humanos em sua forma abstrata e descontextualizada pouco significam. Como esta noção é traduzida na prática - e suas conseqüências particulares - depende de relações de poder forjadas em contextos históricos específicos e expressas em categorias semânticas precisas. Partimos do pressuposto de que a "frente discursiva" - fruto da negociação entre diversos grupos de interesse trabalhando em torno de um mesmo tema - é uma faca de dois gumes. Por um lado é fundamental para mobilizar apoio político em bases amplas e eficazes. Por outro lado, tende a reificar o grupo alvo de preocupações, alimentando imagens que pouco têm a ver com a realidade. Nossa hipótese é que se os ativistas dos direitos humanos não mantêm um certo distanciamento em relação a este jogo discursivo, correm o risco de montar programas que não apenas deixam de alcançar os seus objetivos mas, pior que isto, produzem novas formas de exclusão.

Introduzido com uma reflexão sobre a natureza e importância da "frente discursiva" de que falamos, este artigo começa com a descrição de um caso exemplar - a construção social e histórica da categoria "indígena". Em seguida, adentra outra "frente", a da infância, e sua constituição enquanto problema social. A parte principal concentra-se na análise de programas para a institucionalização de crianças e adolescentes na FEBEM-RS, tentando ver como certos processos desencadeados pela legislação progressista acabam

3 Ver também "a produção discursiva da realidade" e a "codificação estratégica" no campo de correlações de força em Foucault (1977); ver também Bourdieu (1980).

Horizontes Antropológicos, Porto Alegre, ano 5, n. 10, p. 83-121, maio 1999 
produzindo efeitos inesperados. Sua intenção é mostrar como os eventuais efeitos negativos da legislação são muitas vezes produzidos por dispositivos discursivos que escapam à vontade consciente dos indivíduos. Finalmente, $o$ artigo situa a "infância" como um discurso entre outros que mobilizam campanhas de direitos humanos e que nem sempre surtem os efeitos desejados.

Ao atentar para a maneira como uma categoria ć priorizada em detrimento de outras, desvendamos lutas simbólicas que vão bem além da briga entre ONGs por financiamentos escassos. Começamos a ver critérios particulares que determinam - na reivindicação de direitos - quem é mais, e quem é menos, humano.

\section{A organização de uma frente discursiva - o caso do índio pataxó}

Brasília, capital federal. Numa noite de sábado, abril de 1997, quatro jovens abastados, para exorcizar o tédio, fazem sua escolha medonha de diversão: interromper o sono de algum mendigo, encharcá-lo com gasolina e acender um fósforo. Que espetáculo poderia ser mais gratificante para os seus olhos lerdos do que uma figura em chamas gesticulando e rolando desesperadamente, tentando em vão extinguir o fogo? Acontece que, para infelicidade dos rapazes, o "mendigo" que escolheram era um índio pataxó, recém-chegado à capital para uma comemoração especial: o Dia Nacional do Índio. E, assim, a história deles - que nós leitores de jornal soubemos posteriormente não ser nada incomum (em média, um mendigo por mês é incendiado na maioria das grandes cidades brasileiras) - terminou mal. Confrontados pela opinião pública com a gravidade de sua "brincadeira", os rapazes esboçaram o que, evidentemente para eles, era uma desculpa plausível: "A gente não sabia que era um índio, pensamos que era um mendigo qualquer."

O que nos interessa neste episódio não é tanto a violência. Esta já se encontra amplamente representada no histórico brasileiro. Nomes como Carandiru, Candelária e Diadema tornaram-se nos últimos anos sinônimos da brutalidade institucionalizada contra os fracos. ${ }^{4} \mathrm{O}$ incidente de Brasília,

\footnotetext{
4 Estes nomes correspondem respetivamente a: a prisão paulista onde 111 detentos foram sumariamente executados pelos guardas, o bairro central da cidade do Rio de Janeiro onde seis crianças de rua foram assassinadas por um esquadrão da morte (ver Alvim, 1995), e o subúrbio de São Paulo onde policiais foram filmados espancando e matando com um tiro pelas costas um cidadão arbitrariamente detido para suposta verificação de documentos.
}

Horizontes Antropológicos, Porto Alegre, ano 5, n. 10, p. 83-121, maio 1999 
todavia, é um dos poucos em que tivemos acesso às atitudes expressas por cidadãos comuns para justificar tais barbaridades. Ao apresentar tudo como um mal-entendido - como se fosse permissível, ou em todo caso menos condenável, atear fogo num mero mendigo - os rapazes trazem à tona um sistema de classificação que separa os humanos dos não-humanos.

Para melhor entender os processos de exclusão - objetivo desse artigo seria útil, como preâmbulo, refletir sobre como uma categoria, neste caso "o índio", conseguiu alcançar seu status de mais humano.

Os antropólogos brasileiros desempenharam historicamente um importante papel neste processo enquanto militantes da causa indígena apoiando as reivindicações destes grupos nas instâncias políticas adequadas. Hoje, acrescentam uma contribuição de outra ordem - desconstruindo conceitos naturalizantes de identidade étnica, dando claras demonstrações de como a política indigenista e outros fatores contextuais determinam nossa maneira de olhar para esses “outros". O trabalho de M. Arruti (1997) é exemplar. Aprendemos com este autor que no final do século dezenove os colonos e seus legisladores, ávidos por novas terras, já tinham declarado os "índios" uma coisa do passado: "Extintos os aldeamentos e libertos os escravos, aquelas populações deixam de ser classificadas, para efeito dos mecanismos de controle, em termos de índios e negros, passando a figurar nos documentos como indigentes, órfãos, marginais, pobres, trabalhadores nacionais." (Arruti, 1997, p. 17, grifo nosso). A modificação de termos teve por objetivo constatar uma versão conveniente da realidade. Do ponto de vista dos mecanismos de controle, a repressão do "pobre" é mais facilmente justificada do que a repressão do "índio" e, certamente, essa aniquilação semântica dos povo indígenas teria surtido efeito em pouco tempo se as formas de classificação, sob novas influências, não tivessem mudado.

No início deste século, com a consolidação de uma identidade brasileira, a "indianidade" volta à tona entre as elites como emblema nacional (Freyre, 1978; DaMatta, 1991; Oliven, 1992). As populações indígenas são redescobertas e, apesar da grande maioria não ser considerada "autêntica" (mas apenas "remanescente"), reconhece-se a especificidade de seus direitos. As conseqüências desta nova visão não tardam a se manifestar. A partir de um decreto de 1928 que estabelece o status jurídico de índios, uma variedade de grupos começa a descobrir suas origens indígenas. Uns ostentam tradições 
“autênticas", outros já converteram-se a um modo de vida muito semelhante ao de seus vizinhos camponeses. Uns têm aparência física "adequada" ao status reivindicado; outros, portando a gama de nomes de uma população miscigenada - cafuzo, mameluco, caboclo - parecem mais negros ou brancos do que o folclore legal gostaria. Mas, da mesma forma que, algumas décadas antes, tinham deixado de ser vistos (e, eventualmente, de se verem) como "índios", agora, frente a novas circunstâncias políticas, passam a reconquistar esta identidade. A partir desta conjuntura, torna-se evidente (pelo menos, para os antropólogos) que "ser índio" se remete menos à descendência de algum povo pré-colombiano do que à identidade expressa por determinada coletividade "sendo índios todos os indivíduos que são por ela reconhecidos enquanto membros desse grupo étnico" (Pacheco, 1995, p. 79).

A reviravolta semântica acaba produzindo o fenômeno que descreve. Nas últimas décadas do século XX, com a chegada das ONGs, das alianças internacionais e da associação dos povos indígenas à questão ecológica, vemos pela primeira vez na história não apenas uma modesta expansão demográfica mas também um crescimento do número de tribos classificadas. Povos indígenas, apoiados pela Constituição de 1988, redescobrem ritos longamente esquecidos (Rosa, 1998) e aceleram suas reivindicações à demarcação das terras. As visões essencialistas que ancoram a "indianidade" -genética ou culturalmente - nalguma mítica esfera pré-colombiana parecem ter caducado. Para enfatizar o caráter dinâmico e contemporâneo das "nações" indígenas, a frase de efeito atual refere-se a "comunidades emergentes".

A literatura sobre populações indígenas nos incita a refletir sobre as conseqüências dos termos que utilizamos. Hoje merece nosso reconhecimento o fato de ter sido criada, graças ao esforço conjunto de antropólogos, ONGs e um bom número de líderes indígenas, uma nova frente discursiva para resgatar as 200 nações indígenas do ostracismo histórico e reinstalar os seus membros como cidadãos de tempos modernos. Resta saber o que acontece com aqueles - a vasta maioria da população - que não foram rebatizados.

O episódio do índio pataxó nos ajuda a colocar em relevo o poder instituinte das palavras, isto é a construção social de certas categorias ("índios", "crianças", "mendigos") enquanto mais ou menos merecedoras de direitos específicos. Nove vezes em dez, as flagrantes violações de direitos humanos 
no Brasil não são perpetradas contra grupos minoritários específicos, mas sim contra os pobres - as outras vítimas queimadas vivas que, por serem "meros mendigos", nem aparecem nos jornais. Que tipo de frente discursiva pode-se organizar para uma categoria tão desgraçada como os "pobres" e "indigentes"?

\section{Categorias sociais e direitos humanos- a infância como problema social}

Desde a década de 70, pesquisadores do campo sociológico têm dedicado atenção à maneira como um ou outro tipo de comportamento acaba sendo eleito, pela opinião pública, como "problema social". ${ }^{5}$ Tentam entender os processos que definem os temas de destaque - as "causas" que, em determinada conjuntura, comovem o público, angariam fundos, e mobilizam frentes de ação. Essa linha de investigação não nega a importância dos temas destacados; apenas sugere que não existe uma relação direta entre a gravidade do problema e o tamanho das atenções (volume e intensidade emocional) voltadas para ele. O que consta - na opinião pública - como "mais urgente" depende nem tanto da "realidade" quanto de prioridades mediáticas, oportunismo político, e sensibilidades de classe.

Como explicar que em Recife, por exemplo, existiam em 1992 nada menos de 298 trabalhadores sociais especializados no atendimento de meninos na rua para uma população alvo de menos de 250 jovens (Hecht, 1998, p. 152)? Por que não haveria proporções semelhantes de trabalhadores para crianças pobres morando em casa já que existem fortes sinais que são essas as crianças mais sujeitas a violência e mal nutrição (Hecht, 1998; Silva; Milita, 1995)? Por que a imprensa internacional dá tanta cobertura aos esquadrões da morte quando mal menciona formas infinitamente mais comuns de violência contra crianças tais como tortura pela polícia (Hecht, 1998, p. 23)? O inconveniente não é o fato de dar visibilidade a casos assumidamente problemáticos - meninos vivendo na rua, o assassinato de pessoas indefesas... O risco é que a forte carga emocional destes temas mediáticos crie uma cortina de fumaça, ofuscando a análise de problemas mais abrangentes e dificultando a possibilidade de "soluções" conseqüentes.

5 Ver Best (1990), Blumer (1971) e Conrad e Schneider (1992).

Horizontes Antropológicos, Porto Alegre, ano 5, n. 10, p. 83-121, maio 1999 
As estimativas inflacionadas quanto ao número de "crianças abandonadas" é um exemplo desse processo. Extrapolando a definição legal, o termo "abandonado" vai se aplicando a um universo mais amplo (atinge, em certos documentos da UNESCO, 30.000.000!), tornando-se praticamente sinônimo de "criança pobre". Se, por um lado, esse tipo de exagero presta-se a campanhas de valor consensual tais como saúde infantil e educação, não podemos ignorar que aparece, por outro lado, em discursos controvertidos: para justificar a esterilização de mulheres pobres, por exemplo, ou para advogar a adoção de crianças pobres como solução da miséria.

Rosemberg (1993, p. 71), comentando o uso mediático de dados inflacionados sobre "meninos de rua", ${ }^{6}$ mostra claramente como uma certa histeria ligada à idéia da criança pobre faz tudo menos ajudar a remediar a situação:

[...E]ste esforço de sensibilizar a opinião pública quanto à violência a que são expostas crianças e adolescentes principalmente dos países subdesenvolvidos, gerou uma retórica específica que vem percorrendo o mundo, e que, no seu esforço de convencimento, muitas vezes incorpora diagnósticos catastróficos, inverossímeis, distantes da realidade, estigmatizadores de famílias, crianças e adolescentes pobres, e inadequados enquanto balizas para a ação.

Começamos, portanto, a suspeitar que a grande preocupação demonstrada globalmente pelo valor "criança" não é sempre ligada a observações objetivas, avaliações corretas da realidade, ou campanhas eficazes que revertem em qualquer benefício real das crianças ou suas famílias. Muito pelo contrário, parece existir, em certas situações, uma razão inversa entre o volume de retórica e a eficácia das políticas.

\section{Um campo de pesquisa: a FEBEM-RS}

Propomos agora tornar nossas atenções para uma recente pesquisa sobre a rede institucional do principal órgão do Rio Grande do Sul responsável pelo bem-estar de crianças e adolescentes - a FEBEM-RS. A pesquisa foi realizada

6 Trata-se, por sinal, de números abraçados e repetidos por órgãos nacionais (FEBEM) e internacionais (UNICEF). 
em 1995-7 por membros do NACI (Núcleo de Antropologia e Cidadania) ${ }^{7}$ com o intuito de testar o impacto do Estatuto da Criança e do Adolescente na vida dos "clientes" desta instituição - na sua maioria esmagadora, famílias pobres. Cabem duas ressalvas na introdução deste material. Em primeiro lugar, apesar de concentrar nossos esforços em problemas inerentes à institucionalização de crianças e adolescentes, devemos lembrar que o trabalho da FEBEM não se limita a isso. Pelo contrário, a FEBEM-RS trabalha com uma vasta rede de serviços, a maioria voltada para jovens não-institucionalizados. Muitos destes programas são relativamente bem sucedidos. Porém, menos visados pela opinião pública, acabam sendo deixados de lado por jornais e pesquisadores que tendem a reduzir o trabalho desse órgão estatal a um único aspecto: os programas para infratores.

Em segundo lugar, devemos ressaltar a postura "dialógica" que nossa equipe de pesquisa manteve com os administradores da FEBEM durante a pesquisa. Nosso interesse pelas casas de contenção surgiu de um convite estendido por dois técnicos da "casa feminina", propondo que a equipe do NACI realizasse um estudo sobre a qualidade de vida das egressas. A parceria com esse órgão, o tipo normalmente execrado em pesquisas acadêmicas, exige explicações.

Ao consultar trabalhos já realizados sobre crianças institucionalizadas, ficamos impressionadas por certas lacunas. Existe um amplo estoque de literatura sobre as causas estruturais da "marginalidade" (principalmente na década de 70), sobre as conseqüências nefastas da institucionalização para o desenvolvimento da personalidade dos jovens (na década de 80) e, mais recentemente, sobre a moralidade conservadora e morosidade tradicionais do judiciário que criam obstáculos à realização do espírito da Constituição. ${ }^{8} \mathrm{Cada}$ escola de análise traz contribuições importantes. No entanto, percorre quase todas as obras um tom apocalíptico em que os administradores e funcionários das instituições parecem representar as forças do mal. Parece subentendido

\footnotetext{
Pesquisa realizada no âmbito do PPG em Antropologia Social da UFRGS. com financiamento do CNPq e FAPERGS e envolvendo, além das autoras, Elisiane Pasini, Heloisa Paim, Alinne Bonetti, Marta Jardim e Fernanda Ribeiro. Essa pesquisa teve continuidade em 1998 com o Projeto Integrado de Pesquisa sobre os Adolescentes Privados de Liberdade e Internos na Fundação do Bem-Estar do Menor pela Prática de Ato Infracional sob a coordenação de Profa. Carmen Craidy, FACED-UFRGS.

8 Ver Schneider (1982), Guirado (1982), Violante (1985), Altoé (1990), Adorno (1991), Méndez (1993) e Passetti (1995).
} 
que se somente fosse possível substituir esses autômatos da instituição total por uma equipe de pessoas "esclarecidas" (cientes, entre outras coisas, das críticas analíticas do pesquisador) as coisas poderiam ser melhoradas. Esse tipo de abordagem tende a reforçar a hierarquia de prestígio que coloca a teoria acima da prática e, por extensão, a sabedoria dos planejadores acima da dos agentes sociais que executam as políticas.

No caso de nossa pesquisa, não foi tão fácil traçar esse tipo de distinção entre nós e os administradores da FEBEM. Desde a promulgação do ECA, os governadores do Rio Grande do Sul, independentemente de sua afiliação partidária, escolhem presidentes da FEBEM entre os militantes dos direitos da criança. Em geral, o/a presidente compõe uma diretoria de profissionais (psicólogos, pedagogos, assistentes sociais) que também têm longa experiência na área dos direitos humanos. São escolhidos para executar a política os mesmos agentes sociais - integrantes de movimentos sociais - que ajudaram a formular o ECA. A partir de 1995, em particular, houve uma campanha para efetivar os princípios do ECA na vida institucional de todas as casas da FEBEM-RS. Desta maneira, ao iniciar nossa pesquisa, tínhamos a confrontar quadros que, em muitos casos, não somente conheciam os trabalhos de Goffman e Foucault tão bem quanto nós, mas que tinham um intenso compromisso com questões de justiça social e cidadania.

Nosso projeto de pesquisa objetivou, desde o início, tomar os "agentes sociais" não como inimigos (em oposição às "forças aliadas" intelectual/classes populares) mas, sim, como interlocutores - analistas e analisados - que deviam ser ouvidos. ${ }^{9}$ Reconhecer que nossos "nativos" não eram ingênuos nos obrigou a rever o papel do antropólogo nesta interlocução. Mais desconcertante ainda, nos obrigou a reconhecer que a distância que nos separava não era tão grande assim, que éramos - de ambos lados - parte de um mesmo "processo civilizatório". Qualquer análise deles implicaria forçosamente na análise de nossos próprios valores.

\footnotetext{
9 Embora o espaço não permita maior discussão sobre este item, devemos lembrar que este campo - que inclui políticos, juristas, cientistas sociais, administradores, monitores, educadores e outros técnicos profissionais - não é, de forma alguma, homogêneo. Há, em particular, uma tendência para as diferentes categorias profissionais marcarem seu território e sublinhar a importância de seu trabalho destacando as deficiências de categorias logo abaixo ou logo acima na escala de prestígio (ver Bourdieu, 1977).
}

Horizontes Antropológicos, Porto Alegre, ano 5, n. 10, p. 83-121, maio 1999 
Não obstante os valores e objetivos em comum, havíamos no entanto de reconhecer que, enquanto pesquisadores, ocupávamos um lugar diferente em relação à realidade pesquisada. Ao técnico, cabe agir e, no ato, travar uma política clara de opção entre múltiplas possibilidades. O pesquisador, liberado desta responsabilidade, se entrega a um número sem limite de digressões, algumas mais relevantes do que outras. Tomamos então como tarefa aproveitar a relativa liberdade de nosso lugar "distanciado" para ir além de problemas imediatos e vasculhar estruturas que não eram aparentes no decorrer de atividades cotidianas. Para tanto, tornamos nosso olhar para as estruturas embutidas na linguagem que usamos para pensar o mundo - o conteúdo moral dos termos empregados para classificar os comportamentos e, por extensão, as pessoas que passam pelo sistema institucional.

\section{De como não bastam as boas intenções}

Na discussão sobre a institucionalização da infância pobre, uma coisa se torna evidente: que a mudança de leis implica numa mudança de categorias de classificação. Assim, com o ECA, o termo "menor" foi descartado porque reduzia a criança pobre a uma categoria jurídica penal; "medida sócio-educativa" tomou o lugar de "internação" para lembrar a todos a finalidade dessa privação de liberdade e "adolescente autor de ato infracional" veio substituir "menor infrator" para diminuir o estigma que tende a rotular o jovem como delinqüente. ${ }^{10}$ Atrás de cada mudança há uma história de criticas que visaram avançar o debate.

$\mathrm{Na}$ verdade, desde o início da época moderna, a ciência tem procurado refinar suas categorias quanto aos "desviantes" - aqueles indivíduos que, por serem marginais econômicos, párias sociais, delinqüentes ou "alienados", destoavam no cenário supostamente harmonioso da sociedade vigente. Tomando corpo no fim do século XIX com as teorias lombrosianas da antropologia criminalista (Corrêa, 1997), a ânsia científica de separar esses "outros" em categorias apropriadas, corria paralelo à preocupação de moralistas e educadores. Por um lado, era preciso travar programas específicos para disciplinar e

${ }^{10}$ Para a evolução da legislação sobre crianças e adolescentes no Brasil, ver Alvim e Valladares (1988), Passetti (1991), Ribeiro (1998). 
recuperar os elementos com comportamento anti-social; por outro, era necessário proteger crianças "abandonadas" de qualquer contaminação que pudesse decorrer do contato diário com os infratores. Assim, há mais de um século, reformadores procuram distinguir i"crianças perigosas" de "crianças em perigo" (Meyer, 1977).

A realidade, no entanto, nem sempre se presta a uma categorização tão fácil. Aprendemos dos historiadores que, desde a acepção das instituições públicas para "menores", afloram ambigüidades quanto à categorização dos internos: são “delinqüentes", “órfãos”, ou “abandonados"? Muitas vezes a miséria é tal que os pais - mesmo os legalmente casados - recorrem à institucionalização para suprir as necessidades básicas do seu filho - ora sob cobertura do anonimato "expondo seus filhos na roda", ora barganhando "uma vaga" em internatos filantrópicos e governamentais (Donzelot, 1980; Fonseca, 1995). Sem dúvida, por causa da demanda excessiva, as instituições governamentais tentaram classicamente dar um basta a esse tipo de internação, reservando a maior parte de suas facilidades não para crianças necessitadas, mas sim para crianças indisciplinadas - aquelas que supostamente representavam uma ameaça à sociedade ou que, sem medidas especiais, viriam futuramente a representar uma ameaça. Mas tal politica criou inadvertidamente uma nova ambigüidade - entre os carentes e os perigosos - pois os próprios pais, diante da recusa obstinada dos "internatos" onde procuravam colocar seus filhos, começaram a sublinhar, como motivo de internação, o comportamento insubmisso de sua prole. ${ }^{11}$

No Brasil, apenas na última década houve um esforço de "racionalizar" o atendimento ao jovem infrator, separando os casos mais graves - que representam uma "verdadeira ameaça" à sociedade - dos demais. Antes do ECA, não era incomum achar na mesma casa "infratores" misturados com "abandonados" e "carentes". ${ }^{12}$ Com o ECA, instaura-se uma clara separação entre duas categorias de jovens institucionalizados: por um lado o "abandonado", por

${ }^{11}$ Aprendemos de B. Brenzel (1983, p. 7) que, desde a primeira "reform school" para meninas em Massachusetts (aberta em 1856), os pais pobres aprenderam a manipular o sistema para conseguir admissão: "In hard times, parents often sought the only relief available to them; in complicity with the law. they condemned their children as stubborn and disorderly."

${ }^{12}$ Silveira (apud Rizzini et al., 1992), em pesquisa sobre o Centro de Recepção e Triagem da FEBEM-CE, afirma que. antes do ECA, até $30 \%$ das meninas foram internadas por desobediência aos pais, e $25 \%$ por perambulância. Pelligrini et al. (1996), na sua pesquisa sobre duas casas de "infratores" da rede FEBEMRS, mostram que ainda em 1988 quase um terço dos jovens tinham sido internados sem cometer um delito.

Horizontes Antropológicos, Porto Alegre, ano 5, n. 10, p. 83-121, maio 1999 
outro lado o "adolescente autor de ato infracional". Ao mesmo tempo, toma-se mais difícil institucionalizar um jovem: "Nenhum adolescente será privado de sua liberdade senão em flagrante de ato infracional ou por ordem escrita e fundamentada da autoridade judiciária competente.” (art. 106).

Com a nova legislação, nota-se um esforço de aproveitar lições do passado. Ainda mais, passa-se a reconhecer a importância de categorias classificatórias para o atendimento a jovens e crianças. Consideramos, no entanto, que estes avanços teóricos não substituem o conhecimento da realidade concreta em que a lei atua. A eficácia e até a justiça de determinados dispositivos jurídicos não podem ser planejadas fora do contexto concreto. Pretendemos demonstrar, pelo estudo de algumas mudanças ocorridas no sistema estadual de atendimento ao adolescente e a criança no Rio Grande do Sul, como a promoção dos direitos humanos exige mais, muito mais, do que uma legislação "ideal".

\section{A "escalada de violência"}

Ao longo dos últimos anos, houve uma aceleração de artigos jornalísticos sobre a escalada de violência nas FEBEMs das principais capitais do país. Apesar de ser chefiada, de 1995 a 1998, por uma presidente com longa carreira na luta pelos direitos da criança e do adolescente, a FEBEM-RS não foi uma exceção. Em junho de 1998, cerca de um mês depois da morte de três jovens, queimados vivos nas suas celas, a Zero Hora iniciou uma série de reportagens intitulada: "O Dossiê FEBEM: Casa de Horrores". O quadro noticiado não deixa de causar efeito: 31 motins desde 1995, dez apenas nos primeiros seis meses de 1998. Em pouco mais de dois anos, nove mortes: além dos três jovens asfixiados, três enforcados (suicídios presumidos), e os restantes mortos de doença.

A casa masculina de contenção máxima, o ICM, estava em ruínas. No final de 1997, depois de reconhecer que a administração tinha "perdido controle", o governador introduziu no funcionamento diário da casa integrantes da Brigada Militar. A estratégia, evidentemente, não surtiu efeito. Os motins continuaram no mesmo ritmo. Muros de concreto iam sendo demolidos para permitir o confronto de gangues rivais. Salas de atendimento e celas foram 
progressivamente desativadas por causa de repetidos incêndios (o fogo era empregado por internos como forma de protesto, de fuga, ou simplesmente de chamar atenção dos monitores). Por causa de automutilação e brigas, os jovens internos necessitavam de freqüente atendimento hospitalar. Ironicamente, apesar de os abusos físicos perpetrados por funcionários contra internos estarem sob controle (o número de sindicâncias abertas para investigar surras e tortura física tinha baixado a praticamente zero), os jovens sorriam ameaça constante de violência da parte de outros internos.

Os meninos mostravam-se artistas na fabricação de armas caseiras, inventando estiletes praticamente do ar. Podiam passar, por exemplo, um dia inteiro esfregando um fio de violão contra a grade da janela, para cortar o ferro e aproveitar esse pedaço de metal. Outra arma freqüentemente usada era o fogo. Mesmo sem fósforo, conseguiam criar faísca suficiente encostando dois fios elétricos. Num episódio típico daquela época, os meninos tentaram evitar uma revista que implicaria na perda de suas armas. Ameaçaram a administração da instituição: "se vocês teimarem em fazer revista, vamos botar fogo nos colchões". A revista foi feita, as armas confiscadas, e o fogo ateado e apagado por funcionários. Era simplesmente mais um dia na vida institucional. ${ }^{13}$

Não pretendemos nos deter aqui na análise dessa crise. As circunstâncias particulares do caso - a tentativa de introduzir uma "nova proposta pedagógica" norteada pelos princípios do ECA, a proibição de castigos físicos, e os motivos da não-cooperação de alguns funcionários "antigos" - mereceriam um artigo à parte. $\mathrm{O}$ que nos interessa aqui é que esse episódio faz parte de um padrão nacional de problemas crescentes com adolescentes institucionalizados. Como devemos interpretar esse fato? Como prova da maior incompetência das autoridades responsáveis? Como reflexo da escalada de violência na sociedade como um todo? Sem negar a relevância dessas explicações em contextos específicos, gostaríamos de sugerir que existe outra causa mais abrangente, e que faz parte de estruturas desencadeadas pelo próprio ECA.

13 Episódio registrado no diário de campo de Elisiane Pasini durante pesquisa etnográfica no âmbito do Projeto Integrado Adolescentes Privados de Liberdade e Internos na Fundação do Bem-Estar do Menor pela Prática de Ato Infracional. 
Lembramos que, até a promulgação do ECA, era praxe no Rio Grande do Sul, corno no Brasil inteiro, institucionalizar jovens com ou sem ordem judicial. Os autores do Estatuto, zelando pelos direitos da criança e do adolescente, propuseram limitar o número de jovens internados, estipulando que ninguém seria privado de liberdade senão em flagrante do ato infracional ou por ordem da autoridade judiciária. Depois de 1990, sob o impacto de uma equipe de administradores procurando viabilizar o Estatuto, houve, nas sete casas para infratores no Rio Grande do Sul, uma queda dramática do número total de jovens ingressando no sistema. ${ }^{14}$ Entre 1990 e 1991, esse número (que inclui todos que passaram pela casa, que fiquem um dia ou três anos) caiu mais de 65\%: de 3317 internos para 1109 .

Depois desta queda, o número total de internos começa uma lenta escalada. Tal fato é compreensível considerando que o ECA ainda prevê a institucionalização, depois de esgotadas todas as outras possibilidades, de ofensores

\section{Número total de ingressos no ano}

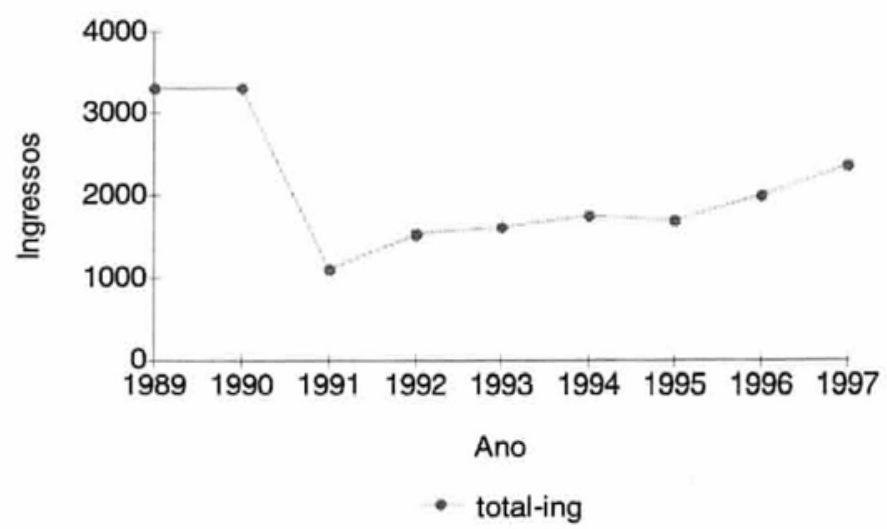

14 As quatro casas principais do estado, localizadas em Porto Alegre, incluem o Instituto Juvenil Masculino (IJM que iniciou suas atividades em 1973), o Instituto Central de Menores (ICM - 1962), o Instituto Carlos Santos (ICS - 1991, e o Instituto Educacional Feminino (IEF - 1962). No interior do estado, temos o Instituto de Recepção Iracema Cassei do Canto (IRICC em Santa Maria - 1989), o Centro Educacional Vítor Hugo Rocha Ribeiro (CEVHRR - 1885) em Uruguaiana, e o Centro de Ressocialização do jovem Infrator (CRJI - 1993) em Cachoeira. No final de 1998. iniciou-se a inauguração de dez Centros de Juventude, casas com até 40 infratores, a fim de decentralizar o atendimento ao autor de ato infracional.

Horizontes Antropológicos, Porto Alegre, ano 5, n. 10, p. 83-121, maio 1999 
crônicos. ${ }^{15}$ Mas seis anos mais tarde, o numero total de meninos privados de liberdade ainda não chega a igualar o número pré-Estatuto. Num primeiro momento, podemos considerar que o ECA surtiu o efeito desejado.

Entretanto, ao considerar o número de jovens internados apenas no último dia do ano, ficamos com a impressão de uma evolução oposta àquela prevista pela legislação. O número de internos aumentou de 208 em 1990 para 529 em 1997, ou seja, dobrou, apesar de um acréscimo populacional para os jovens gaúchos dessa faixa etária de apenas $8 \%{ }^{16}$

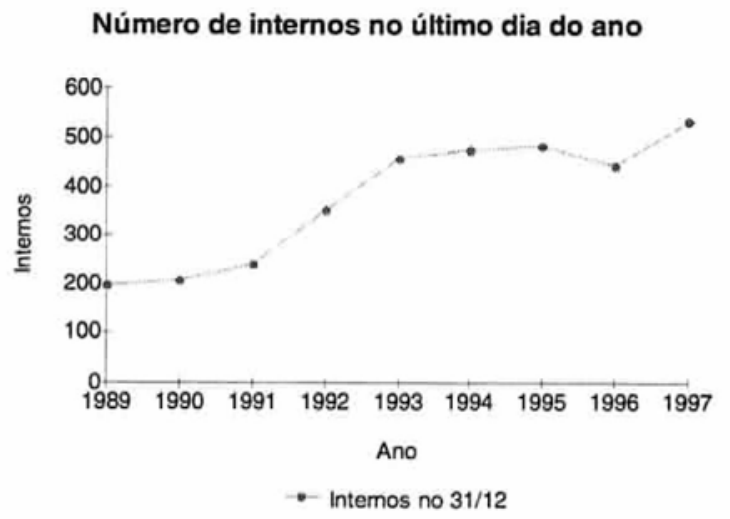

Como explicar o paradoxo das duas curvas seguindo rumos opostos: o aumento de crianças institucionalizadas num mesmo dia apesar do decréscimo do número total de internações? A explicação aparente é que os jovens internados permanecem mais tempo na FEBEM do que antes do ECA. Há uma certa lógica nessa hipótese (não obstante os dispositivos do ECA que colocam limites explícitos ao tempo de internação).

Com o ECA, o perfil dos infratores começou a mudar. A partir desse momento, os autores de infrações leves passaram a receber medidas sócio-educativas relativamente brandas: advertências, prestação de serviços à comunidade, liberdade assistida - tudo menos a institucionalização. Sobraram

15 O “descumprimento reiterado e injustificável de medidas anteriormente impostas" (art. 122), justificaria a medida mais severa de privação total de liberdade.

${ }^{16}$ Conforme o levantamento por Volpi (1997), depois de São Paulo, Rio Grande Sul possuía o maior número de adolescentes autores de ato infracional privados de liberdade no Brasil. 
para a instituição apenas os jovens autores de crimes graves - aqueles que ficam mais tempo internados. Ainda mais, houve nessa época uma racionalização do espaço que mudou a política de fugas.

Até o início da década de 90, a fuga era extremamente comum, tacitamente tolerada (segundo alguns funcionários) como maneira ex-ofício de aliviar a superlotação das instituições. Devemos lembrar que a mobilidade geográfica é, para muitos dos meninos, uma maneira tradicional para lidar com situações de conflito dentro e fora da instituição. Hecht, escrevendo sobre meninos de rua em Recife, sugere que quando surgem conflitos incontornáveis na rua, os jovens tendem a simplesmente mudar de moradia. Lançam mão da mobilidade espacial para evitar confrontações. "Assim se esses conflitos ocorrem num abrigo, a resolução mais evidente (e a única alternativa à violência) é ir-se embora" (Hecht, 1998, p. 178). Antes do ECA, as casas de contenção não eram muito diferentes dos abrigos nesse respeito.

Diz-se que os próprios monitores sabiam prever momentos de tensão e, para prevenir contra motins e brigas, facilitavam então fugas.

Depois do ECA, a taxa de fugas foi cortada pela metade. A redução de fugas não teria sido possível sem a reorganização da rede institucional, que indicava uma distribuição dos infratores de acordo com sua suposta periculosidade. A partir de 1991, uma das casas de contenção máxima, o ICM, passou a ter como clientela exclusiva os adolescentes que cometeram "um crime contra a pessoa". Os "crimes contra o patrimônio" continuaram a ser distribuídos entre as casas restantes. Simultaneamente, foi inaugurada uma instituição voltada para internos em regime de "semiliberdade" e com possibilidade de atividade externa, o ICS, de onde a maioria saía em pouco tempo - pela fuga. Já no primeiro ano do ICS, quase a metade dos internos se desligou por fuga e, ainda em 1996, a porcentagem de desligamentos por fuga chegava a mais de três quartos da população interna. À medida em que as fugas cresciam no ICS, baixavam nas casas "de alta periculosidade" a quase zero. (Entre 1991 e 1992, na época de implantação da nova política, as fugas caíram nas três casas de contenção máxima: de $15,2 \%$ para $7,4 \%$, de $28,8 \%$ para $4,9 \%$ e de $20,8 \%$ para $6,9 \%$.)

É evidente que essa maior eficácia na contenção de jovens responde a uma demanda política de remover os "elementos mais perigosos" da circulação pública. Significa, por outro lado, uma situação inusitada para a qual poucas instituições estavam preparadas. 
Nos últimos dez anos, foram feitas no mínimo quatro pesquisas sobre o perfil do infrator da FEBEM-RS, cobrindo os anos 1988, 1991, 1992, 1995 e 1996. Por falta de coordenação entre essas pesquisas, é difícil comparar os diferentes resultados. ${ }^{17}$ No entanto, a base dos dados expostos acima, podemos aventar algumas hipóteses. A soma de certas mudanças - uma maior proporção de autores de infrações graves (portanto com sentenças mais longas), e a contenção de fugas - tem resultado, ironicamente, num novo tipo de superlotação das casas de contenção. Em vez de milhares de jovens - meninos de rua e outros - que passavam alguns dias na FEBEM, agora boa parte dos internos é composta de infratores mais "pesados" que permanecem até três anos no sistema. ${ }^{18}$ Se isso for o caso, então é possível que o aumento de perturbações dentro de certas instituições para infratores não decorra nem de um aumento de violência juvenil na sociedade como um todo, nem necessariamente de uma piora nas políticas institucionais. Sem dúvida, administradores e funcionários deveriam ter previsto essas mudanças para travar novas políticas adequadas à situação. Mas como iam suspeitar que a simples reclassificação de internos ia produzir resultados tão dramáticos?

De certa forma o presidente interino que assumiu a FEBEM durante os últimos três meses de 1998 deu prova de grande perspicácia pois procurou uma solução aos tumultos aproveitando de forma original esse mesmo sistema de classificação. Conforme o ECA, um adolescente privado de liberdade deve

${ }^{17}$ Na época das primeiras pesquisas, era praxe classificar os delitos em "Crime contra o patrimônio", "Crime contra os costumes", "Crime contra a pessoa", etc. Já, a partir dessa perspectiva, temos um problema de interpretação pois o pesquisador é obrigado a reduzir um leque grande de "motivos de entrada" (ameaça, arrombamento, atentado violento ao pudor, busca e apreensão, cumplicidade. desordem em via pública, extorsão, recolhimento...) a três ou quatro grandes categorias cunhadas pelo Código de 1940. As pesquisas mais recentes evitam essas categorias reducionistas, listando ao invés uma multiplicidade de "motivos de entrada". Koller et al. (1996) trabalham com nada menos de 27 categorias, e CAI (1995) emprega em torno de 20. Mas os dois sistemas de classificação coincidem apenas parcialmente. A situação é complicada mais ainda quando lembramos que no mesmo processo constam, em geral, várias acusações contra o "infrator": furto, vadiagem, roubo, tóxicos, etc. Em certos levantamentos, os pesquisadores optam por registar o primeiro delito que consta no processo (Koller et al., 1996). Em outros, os pesquisadores escolhem sistematicamente o delito mais pesado (Pelligrini et al., 1996). Assim, mesmo se trabalhassem com o mesmo universo (o que, em geral, não é o caso), ainda seria difícil comparar os diferentes levantamentos.

${ }^{18}$ Não possuímos dados sobre a evolução da duração da internação dos jovens. A única pesquisa existente no Rio Grande do Sul sobre esse assunto é de Koller et al. (1996) que, na sua pesquisa sobre três das quatro casas de Porto Alegre, encontrou em junho de 1996 (para 239 registros onde consta esse dado) um tempo médio de internamento de 7 meses, e um tempo mediano de 5 meses.

Horizontes Antropológicos, Porto Alegre, ano 5, n. 10, p. 83-121, maio 1999 
permanecer na rede da FEBEM até completar sua pena mesmo se ele atingir a maioridade. Já que a pena máxima para qualquer adolescente é três anos, nenhum jovem fica no sistema além de 21 anos. Porém, ainda há bom número de internos entre 18 e 21 anos. No início de 98, a então presidente da FEBEM, procurando aliviar a tensão nas casas, pediu permissão ao Juizado para transferir os jovens com mais de 18 anos para o sistema penitenciário (de adultos) mas, por respeito ao espírito do ECA, a transferência foi negada. Quando o presidente interino assumiu seu cargo, simplesmente fez uma nova distribuição entre as casas, conforme a idade. Agrupou todos os infratores com mais de 18 anos numa mesma instituição de onde, pelo menos durante o período de transição, tirou os funcionários da FEBEM para colocar guardas do sistema penitenciário de adultos (SUSEPE). Estes, aplicando medidas tradicionais de disciplina, permaneceram o tempo necessário para "botar ordem na casa" sem que nenhuma organização de direitos da criança e do adolescente levantasse objeções. Evidentemente, esses jovens eram contemplados pelo ECA ma non troppo. Bastava a administração isolá-los dos "mais humanos" (com menos de 18 anos) para poder agir em liberdade, sem medo de censura.

\section{Quando os país se agarram aos seus filhos "abandonados"19}

No caso de infratores, procuramos mostrar como a divisão progressiva em categorias cada vez mais delimitadas - abandonado/infrator, alta e baixa periculosidade - originalmente projetada para melhorar o atendimento a adolescentes, acabou por submeter certos desses "autores de ato infracional" a uma situação extremamente explosiva. Agora, propomos olhar para a outra metade do sistema institucional, procurando entender as conseqüências do ECA para crianças "abandonadas". Veremos que, mesmo em condições institucionais praticamente ideais, permanecem dilemas ligados aos direitos humanos - esta vez não somente das crianças mas, também, de suas famílias.

No período de 1991-1995, a administração da FEBEM-RS teve como prioridade o "desmonte dos grandes prédios institucionais para pequenas unidades residenciais", que devia transformar, a longo prazo, todas as grandes

19 O material apresentado aqui é tirado da dissertação de mestrado de Andrea Cardarello (1996). A pesquisa de campo foi realizada no período de setembro de 1994 a junho de 1995. 
unidades de abrigo em "URTs" - Unidades Residenciais Transitórias. ${ }^{20} \mathrm{O}$ início do processo de desmonte deu-se a partir de dezembro de 1991 com o desmembramento, em mais de uma etapa, do Instituto Infantil Samir Squeff (IISS) que abrigava então mais de cem crianças de zero até 6 anos e 11 meses de idade. Em setembro de 1993, com a transferência das últimas crianças do instituto para as URTs, o IISS foi finalmente extinto.

As URTs consistem em pequenas casas projetadas inicialmente para 10 crianças e/ou adolescentes. Seus objetivos seguem os princípios do Estatuto: atendimento personalizado, em pequenos grupos, e a preservação dos vínculos familiares através do não-desmembramento de grupos de irmãos (art. 92).

Desde o início do trabalho realizado junto a técnicos e monitores do Programa, percebemos que este é como uma "vitrine" da FEBEM-RS. O objetivo de um tratamento individualizado foi alcançado: todas as crianças e adolescentes abrigados nas URTs têm acesso a um atendimento especializado, com a atuação de profissionais de diversas áreas como nutricionistas, psicólogos, fonoaudiólogos, fisioterapeutas, professores de educação física e pedagogos. Para reforçar "os processos de integração com a comunidade", também previstos na nova legislação, procura-se utilizar os recursos externos disponíveis. As crianças e adolescentes das URTs freqüentam escolas próximas, são atendidos em postos de saúde e vão a escolas de natação e academias do bairro. ${ }^{21}$ Os relatórios dos técnicos sublinham os resultados positivos desse novo tipo de atendimento - especialmente na área da saúde - e o programa é considerado unanimemente como melhor do que aquele dos grandes institutos. O prestígio que tem junto a órgãos como o Juizado da Infância e da quanto aos culpados. No "Manual de instruções para preenchimento da ficha de tabulação referente ao perfil da clientela nos abrigos da FEBEM" o abandono pressupõe "existência de pais ou responsáveis localizados que se Juventude e

${ }^{20}$ Reconhece-se hoje a necessidade de acabar com os "monstros institucionais" também para autores de ato infracional. Um plano iniciado em 1995 começou a dar frutos ainda em 1998 com a inauguração de "Centros de Juventude". Trata-se de pequenas casas, espalhadas pelo estado onde não mais de 40 infratores poderão travar um modus vivendi que permite um programa pedagógico perto de suas famílias de origem e de reinserção social.

21 Por tudo aquilo que oferece, o programa é um dos mais caros da Fundação. Segundo a coordenadora de abrigos, o custo mensal de um adolescente nas URTs no segundo semestre de 1995 era de 6 salários mínimos (600 reais), e o de uma criança ficava em torno de 10 salários mínimos (1.000 reais).

Horizontes Antropológicos, Porto Alegre, ano 5, n. 10, p. 83-121, maio 1999 
os Conselhos Tutelares, somado à falta de instituições para abrigar crianças na cidade, faz com que vagas sejam constantemente solicitadas.

Em suma, as URTs podem ser consideradas um sucesso. No entanto, $\mathrm{O}$ próprio êxito do programa levanta novos dilemas, pois os jovens que entram nessas casas não foram, na sua maioria, "abandonados". Seus familiares estão no cenário e muitas vezes se opõem à institucionalização. Os técnicos responsáveis pela recomendação (sim ou não) de institucionalização são, portanto, constantemente confrontados ao dilema: deixar a criança com seus familiares ou interná-la?

Trata-se de um dilema alimentado por dois princípios contraditórios do ECA. Se por um lado garante-se a crianças e adolescentes o direito de "ser criados e educados no seio da sua própria família" (art. 19), por outro, devem também ser assegurados seus direitos referentes ao acesso à saúde, educação, alimentação, lazer e esporte, entre outros (art. $4^{\circ}$ ). Em um país como o Brasil, como exigir que as famílias pobres ofereçam tudo isto a seus filhos? Pela lei, a institucionalização numa URT deve ser acionada apenas como último recurso pois viola o direito da criança a ser criada na sua própria família. Por outro lado, a URT garante à criança o restante dos seus direitos, dando a meninas e meninos provenientes das classes mais baixas os confortos de uma vida de classe média. Para resolver o aspecto legal desse debate, é fundamental saber: é a família "negligente" por não garantir o bem-estar de seus filhos? Ou "negligente" é o Estado?

O entendimento diferenciado desta questão entre os técnicos faz com que, dependendo dos casos discutidos, haja posicionamentos distintos. Testemunhamos entre profissionais envolvidos no funcionamento das URTs (juízes, conselheiros tutelares, assistentes sociais, psicólogos) inúmeros debates que demonstravam uma evidente falta de consenso. Algumas pessoas afirmavam que quando a miséria era grande, os pais deviam ser destituídos do pátrio poder. Mostravam, nas suas falas, que a família de origem nem contava como "família": "não importa para onde essas crianças vão, desde que estejam com uma família". O ideal era colocar esses meninos em famílias adotivas. Se isto não fosse possível, era melhor a criança ficar na URT: antes uma criança institucionalizada do que "puxando carrinho, sem escola".

Outras pessoas insistiam que as crianças deviam ficar junto a seus pais. Arguiam que, legalmente, a carência econômica não justifica a 
institucionalização de crianças e a separação dos seus pais. Destacavam situações em que os pais eram manifestamente "afetuosos" para chegar à conclusão: "É melhor uma criança com a mãe debaixo da ponte do que uma criança numa instituição". Finalmente, incorporavam na discussão considerações de teor antropológico, relativizando comportamentos transgressores: "essas pessoas população de rua, etc.) têm uma forma de viver e de educar as crianças que é diferente". Por isso, "não se pode ir pela legislação".

Num esforço de manter o diálogo aberto com os pais das crianças, os membros da equipe se colocavam perguntas constantes quanto à definição de termos tais como "família" e "negligência". Havia, porém, um outro nível, menos consciente, em que esse debate parecia decidido de antemão, dando clara prioridade a medidas autoritárias contra as famílias de origem. Trata-se do sistema de classificação que descreve o motivo de ingresso das crianças no sistema institucional.

\section{0 "aumento" de pais negligentes: uma questão de interpretação}

Ao olhar para esse sistema de classificação, vemos, em primeiro lugar, uma surpreendente multiplicação de categorias nos últimos anos. Durante o ano de 1985, num estudo feito sobre o Instituto Infantil Samir Squeff, os motivos de ingresso das crianças foram agrupados em 10 rubricas principais, estas subdivididas então em mais 19 categorias. ${ }^{22}$ Dez anos depois, em 1995, a FEBEM preparou um levantamento sobre motivos de ingresso de crianças nas URTs onde as 10 rubricas principais de 1985 foram desdobradas em 19, que por sua vez subdividiam-se em nada menos que 251 itens. Incluindo os motivos de ingresso de adolescentes e várias categorias referentes à "insuficiência de dados quanto a...", o número total de rubricas chegava a 45 , subdivididas em 381 motivos diferentes. Parecia existir uma categoria a parte para cada

${ }^{22}$ Os dados sobre o IISS estão baseados no documento Estudo do Atendimento na faixa etária de 0 a 6 anos, que relata que embora no ano de 1985 tenham ingressado no Samir um total de 405 crianças, a defasagem de 55 prontuários não localizados fez com que a população analisada se restringisse a 350 crianças. Em 1\% dos casos não constam dados. Já as informações referentes às URTs têm como fonte o Relatório das atividades do Serviço Social (1994, NAUR - FEBEM) elaborado pelo conjunto de assistentes sociais do NAUR - Núcleo de Assistência às Unidades Residenciais - e o Manual de instruções para preenchimento da ficha de tabulação referente ao perfil da clientela nos abrigos da FEBEM (1994).

Horizontes Antropológicos, Porto Alegre, ano 5, n. 10, p. 83-121, maio 1999 
criança que entrava na instituição. Assim, havia classificações como: "Come no chão com cães", "Mãe bate com facão" ou "Abandono em quarto de hotel".

Mais interessante do que sua proliferação é o aumento sensível de categorias que sublinham a falta moral dos pais e tutores. No documento de 1985, o motivo mais freqüente de ingresso era "Problemas sócio-econômicos" (42\% dos casos). Segundo o relatório, excetuando as categorias de "abandono" e "situação de abandono", o restante, isto é, $81 \%$ de todos os casos, caracterizavam-se por problemas que poderiam ser considerados como sócio-econômicos ou decorrência direta dos mesmos. ${ }^{23}$ Já em 1994, essa proporção é praticamente inversa. Agora quase 3/4 das internações caem em categorias que sugerem a ação maléfica dos pais/tutores adultos: "abandono", "maus tratos", "negligência", "abuso", etc.

\begin{tabular}{|c|c|}
\hline $\begin{array}{l}\text { Motivos de ingresso de } 350 \text { crianças } \\
\text { que entraram no IISS em } 1985(\%)\end{array}$ & $\begin{array}{c}\text { Os dez primeiros motivos de ingresso } \\
\text { das } 207 \text { crianças que entraram nas } \\
\text { URTs em 1994(\%) }\end{array}$ \\
\hline Problema Sócio-econômico: $42 \%$ & Abandono: $26,08 \%$ \\
\hline $\begin{array}{l}\text { Perdido, Perambulação, ou Fuga do Lar } \\
13 \%\end{array}$ & Assistência: 16,42\% \\
\hline Situação de Abandono: 13\% & Maus Tratos: $12,56 \%$ \\
\hline Problema de Saúde dos responsáveis: 11\% & Negligência: 11,11\% \\
\hline Abandono: $6 \%$ & Risco de vida: $10,62 \%$ \\
\hline Maus Tratos: $5 \%$ & Abuso: $4,83 \%$ \\
\hline Desintegração Familiar: 3\% & Mãe na FEBEM: 2,89\% \\
\hline Mendicância: 3\% & Abandono + Maus Tratos: $2,41 \%$ \\
\hline Doenças do Menor: $2 \%$ & Pais doentes mentais: $2,41 \%$ \\
\hline Menor excepcional: $0,5 \%$ & Perdido: $2,41 \%$ \\
\hline
\end{tabular}

${ }^{23}$ Neste documento, até os "maus tratos" são analisados como problema sócio-econômico.

Horizontes Antropológicos, Porto Alegre, ano 5, n. 10, p. 83-121, maio 1999 
A própria definição dos termos adquire um aspecto moral mais pesado. Em 1985, a "situação de abandono" incluía diversas causas. Dizia respeito ao: "[...] menor que possui família ou responsáveis sem condições e capacidade de mantê-lo, não localizados ou ainda, que demonstram desinteresse em assumi-lo" (Estudo..., 1985, p. 22). O "abandono" em si não definia causas ou culpados. Tratava-se do "menor que após verificação de situação irregular pela equipe de colocação familiar de Juizado de Menores é decretado abandonado, e encaminhado para internamento com vistas a adoção" (Estudo..., 1985, p. 22). Já em 1995, a rubrica "abandono" inclui uma porcentagem muito maior $(26,08 \%)$ assim como uma definição que deixa poucas dúvidas quanto aos culpados. No Manual de instruções para preenchimento da ficha de tabulação referente ao perfil da clientela nos abrigos da FEBEM $(1994$, p. 2) o abandono pressupõe "existência de pais ou responsáveis localizados que se negam a assumir os cuidados dos filhos". Seguindo neste mesmo tom, a "negligência/omissão" é definida como "ato ou efeito dos responsáveis de não fazer aquilo que moral ou juridicamente deveriam fazer. Portanto inexiste preocupação com os cuidados.” (Manual..., 1994, p. 3).

A partir da comparação destes dados, não parece sobrar dúvidas quanto ao aumento de comportamentos patológicos. Se, porém, olharmos mais de perto, notaremos que a mudança de comportamento não é tão evidente assim. Vimos, por exemplo, num dos relatórios do Serviço Social do Programa das URTs que "negligência" era assimilada a "casos assistenciais". Ao perguntar a uma das assistentes sociais que elaborou o relatório a razão para esta forma de classificação, ela respondeu: "Isso porque a gente conhecia os casos. Às vezes chama de negligência, mas é assistencial; se confunde. Depende da concepção de quem colocou o motivo, da conselheira tutelar ou assistente social, entendeu? O que é assistencial para uns pode ser negligencia para outros. Por isso a gente somou".

Ainda mais, ouvimos dos entrevistados e lemos na parte narrativa dos relatórios uma queixa que persiste através dos anos: que, em vez de "abandonados", a instituição está abrigando miseráveis. Em 1985, escreve-se: "se houvesse uma maior integração com recursos da comunidade, poderiam ser evitados os internamentos temporários por motivos que não pressupõem recolhimento; possibilitando a estes menores a continuidade do 
vínculo familiar" (Estudo..., 1985, p. 35). O relatório elaborado quase 10 anos depois pelas assistentes sociais do Programa das URTs apresenta queixas semelhantes:

Em Porto Alegre quase inexistem recursos de atendimento a crianças e adolescentes, sendo do Estado, através da FEBEM, a competência de atendimento a esta população, uma vez que ainda não foram criados equipamentos sociais ao nível municipal. Em virtude disso os Conselhos Tutelares, não contando com recursos comunitários à disposição, tendem sempre a encaminhar as crianças para as URTs. Isso é inadequado, uma vez que a unidade de abrigo deveria ser ocupada por situações caracterizadas como de "direito de Estado" (abandono). (Relatório 1994, p. 6-7, ênfase no original).

Levantamos a hipótese de que os casos "assistenciais" ou de "problema sócio-econômico" continuam sendo um problema para a FEBEM. O que parece ter mudado nessa época "pós- Estatuto" é o nome das coisas. As circunstâncias que, antes, eram classificadas como "problema sócio-econômico" estão, hoje, sendo chamadas de "negligência".

A passagem do "problema sócio-econômico" para a "negligência" revela uma mudança de enfoque na visão da infância pobre e da sua família no Brasil. Se em 1985 considerava-se que motivos como "mendicância", "maus tratos", "desintegração familiar" e "doenças do menor" eram decorrência direta de "problemas sócio-econômicos", hoje, mais do que nunca, a família pobre, e não uma questão estrutural, é culpada pela situação em que se encontram seus filhos. E ela que é "negligente", maltrata as crianças, as faz mendigar, não lhes proporciona boas condições de saúde, enfim, "não se organiza". Em suma, parece que a família pobre - e não o "Poder Público" ou "a sociedade em geral" - é o alvo mais fácil de represálias. Cria-se então uma situação particular em que a noção de "criança cidadã" leva como complemento quase inevitável a de "pais negligentes".

\section{Adoç̃o: o post-scriptum do sistema institucional}

O dilema de destituir os pais de seu pátrio poder adquire intensidade em função de outra condição exigida pelo ECA - que a institucionalização seja 
transitória - uma "medida provisória e excepcional, utilizável como forma de transição para a colocação em família substituta"(art. 101). No lugar de "família substituta", leia-se "família adotiva" e as coisas tornam-se mais claras. Antes do ECA, não obstante os protestos dos administradores, a FEBEM era freqüentemente usada como uma espécie de "internato do pobre" (Fonseca, 1995). Considerando a instituição como um recurso complementar à vida familiar, pais pobres deixavam seus filhos internados às vezes durante anos sem abrir mão do pátrio poder. Hoje, simplesmente não existe lugar para tal arranjo. Em princípio, a presença da criança na URT é resultado de uma situação familiar desastrosa. Ou a família de origem corrige a situação, ou a criança deve - idealmente - ser encaminhada para adoção.

O "rapto" ou "tráfico" de crianças tem sido um tema recorrente na imprensa. Ao lado de muitos casos fantasiosos, aparecem aqueles mais concretos sobre Juizados que parecem fornecer uma quantidade sem limite de crianças para adoção internacional. Podemos citar como exemplo uma série de reportagens publicadas na Isto é em 1998 sobre “as Mães de Jundiá'”. Nesta pequena cidade no interior de São Paulo, 484 crianças foram adotadas entre 1992 e maio de 1998 (das quais 204 foram para o exterior). ${ }^{24}$ Hoje, mais de trinta famílias estão protestando que seus filhos lhes foram sumariamente tirados pelo Juizado. Sem ter chance de defesa, e sem nem sequer rever seus filhos depois da institucionalização, os pais se viram destituídos de seu pátrio poder sob acusações não averiguadas de maus tratos, falta de higiene em casa, falta de moradia... (Isto é, 13/05/98, 25/11/98, 28/12/98).

Neste episódio, insinuou-se que autoridades corruptas estavam procurando se enriquecer pelo "tráfico de crianças" dadas em adoção para famílias no exterior. Neste tipo de caso, as coisas parecem simples. É evidente quem está certo, quem está errado. Gostaríamos de sugerir, no entanto, que transita na maioria de FEBEMs do país um drama de vulto bem maior que, por não apresentar um quadro claro de vilãos e vítimas, não recebe a mesma cobertura nos jornais.

${ }^{24}$ Isto é (25/11/1998, p. 110) acrescenta que, no mesmo período, em Campinas - que tem o dobro da população de Jundiaí - ocorreram apenas 40 adoções internacionais. 
Para melhor entender a conjuntura atual, seria interessante trazer à tona uma perspectiva histórica - mantendo presente a pergunta: será que essa complementaridade entre institucionalização e adoção é nova? Ou será que estamos simplesmente repetindo ciclos já conhecidos?

Philippe Aries (1981) nos lembra que a noção de infância é socialmente construída, variando portanto com o contexto histórico. Sugere que na época pré-moderna não existia um sentimento de infância tal como nós a concebemos hoje. Considerada até então simplesmente como um adulto incompetente, a criança adquire, a partir do Renascimento, um novo status. Passa a ser vista como um ser em formação que exige especiais cuidados materiais e afetivos. Surge então um exército de especialistas para melhor definir as necessidades da criança e para aconselhar os pais sobre como criá-la. Vivemos neste século XX o auge desse sentimento com a consolidação das ciências pedagógicas, psicológicas e pediátricas - todas convergindo para um ponto culminante: a criança e adolescente.

A transformação das sensibilidades não se deu, no entanto, sem resistências e tampouco evoluiu num ritmo uniforme em todas as classes. Na Europa, a reorganização da família em torno da criança inicia-se pelas classes abastadas, estendendo-se posteriormente para todas as camadas. A forma como esta extensão se dá nas camadas populares, particularmente na França, é tratada por pesquisadores contemporâneos como um processo de "disciplinarização" (Meyer, 1977; Donzelot, 1980). Esta "disciplinarização" consiste, a partir do século XVIII, em uma verdadeira "guerra" empreendida pelo Estado contra as famílias irregulares, "sociáveis" demais. A família popular é reorganizada em torno da "higiene doméstica", do refluxo para o espaço interior e da criação e vigilância das crianças (Donzelot, 1980, p. 88). Nestas circunstâncias, a criança passa a ser um tipo de "refém" do Estado. Retirar um filho dos seus pais, ou ameaçar fazê-lo, é a arma absoluta nas mãos do Estado e das sociedades de beneficência para impor as suas regras. A norma estatal e a moralização filantrópica colocam a família diante da obrigação de reter e vigiar seus filhos se não quiser ser, ela própria, objeto de uma vigilância e de disciplinarização.

É importante lembrar que, a partir do século XIX, o Estado francês começou a rechaçar a política de institucionalização da infância pobre, 
considerando-a menos eficiente do que deixar as crianças nas suas famílias de origem. Assim, os agentes sociais foram adquirindo meios para negociar com as famílias, fixando as crianças nas suas respectivas casas e realizando os objetivos do disciplinamento. O relato de Donzelot sobre a década de 1970 mostra como assistentes sociais franceses, apoiados em serviços públicos, acham apartamentos arejados para famílias desabrigadas, empregos para os pais "ociosos", tratamento para as mães alcoólatras, e centros educativos para ocupar seus filhos durante as férias.

No Brasil a situação é bem diferente. Ostensivamente, há um repúdio à institucionalização, mas as alternativas são poucas. Embora as assistentes sociais tentem "disciplinar" as famílias populares, exortando os pais a "se organizar", conseguir um emprego, ou construir uma casa maior, elas não têm muito a oferecer em troca. Em geral, não há respaldo estatal na procura por moradias e empregos. Sem ter o que "negociar", resta apenas o recurso da ameaça de retirar as crianças. Lembramos que durante muito tempo, "tirar a criança” de sua família representava um ônus para o Estado que devia então assumir o custo de seu sustento. Que fossem para instituições ou para amas-de-leite e criadeiras, os "órfãos" e "abandonados" custavam caro. Por outro lado, na atual conjuntura, "retirar a criança" não significa necessariamente que esta ficará a cargo do Estado até sua maioridade. As coisas mudaram. Hoje, a adoção, nacional ou internacional, existe como opção palpável na maioria dos casos - desde que os pais sejam destituídos do pátrio poder, ${ }^{25}$ Nesse contexto, a retórica acelerada em torno de "pais irresponsáveis" vem a calhar.

Em certos casos (no Rio Grande do Sul, por exemplo), o trabalho consciente e cuidadoso do Juizado da Criança e Adolescente tem freado o uso da adoção como solução simplista da miséria. Em outros lugares, no entanto, é possível que a noção do "bem-estar da criança antes de tudo" tenha sido usada para aplicar medidas repressivas que mais atropelam do que promovem direitos.

${ }^{25}$ Em outro lugar (Fonseca, 1997), historiamos a explosão de adoção internacional na década de 80 - fator que não deixa de ter um forte impacto sobre a política de atendimento à criança pobre no Brasil.

Horizontes Antropológicos, Porto Alegre, ano 5, n. 10, p. 83-121, maio 1999 


\section{Diversidades em confronto}

É inegável que os rearranjos semânticos ocasionados pelo ECA tiveram forte impacto sobre a realidade dos jovens brasileiros, mas não necessariamente no sentido almejado. Sugerimos que esse desencontro entre intenções e resultados da legislação diz respeito em primeiro lugar à expectativa irrealista de que, pelo judiciário, seja possível solucionar todos os problemas - sociais, econômicos e políticos - que assolam a sociedade. Diante da persistência manifesta da pobreza, os legisladores parecem reagir, antes de tudo, com um desejo de aperfeiçoar as leis. Se as leis não surtem o efeito desejado, é porque mediadores mal preparados não as estão executando fielmente.

Ora, voltamos a insistir, apesar de boa parte do mundo compartilhar hoje princípios humanitários bastante semelhantes, não existe uma legislação ideal capaz de promover estes princípios em todas as épocas e em todos os lugares. Nas sociedades utópicas, projetadas pelos filósofos e seus primos juristas, talvez baste uma regra jurídica aplicada fielmente para garantir a justiça. Para realizar os princípios humanitários em nossa realidade, incomodamente complexa, a história é outra. É preciso a participação ativa dos agentes sociais para adequar o espírito da legislação à diversidade de contextos.

Mas para essa participação ocorrer, os agentes devem, eles mesmos, reconhecer a diversidade de modos de vida e visões de mundo dentro da sociedade - o que não é uma tarefa fácil. Consideremos, como exemplo, a dificuldade que planejadores têm de imaginar diferentes formas de viver e pensar a infância. É sintomático que, quando citam Aries, é para reforçar noções evolucionistas das sensibilidades familiares (usando "pré-moderno" e "moderno" no sentido mais literal e valorativo) em vez de resgatar a lição mais profunda de que todas as sensibilidades - inclusive as modernas - são socialmente construídas.

Para aprofundar esse tema, recorremos à discussão particularmente inspiradora do antropólogo T. Hecht (1998) no seu livro sobre meninos de rua em Recife. Ao examinar a literatura internacional, o autor estranha a maneira como tantos documentos hoje falam da "presença" ou "ausência" da infância, como se essa fase da vida, em vez de ser historicamente construída e portanto de definição variável, fosse uma "coisa" com definição fixa.

Comentando a persistência desta visão anistórica de infância, Hecht descreve outra apropriação indevida dos clássicos - quando Piaget é usado 
para pintar o desenvolvimento psicológico infantil como algo essencialmente biológico, que transcende fatores culturais. Ele ainda argumenta que as organizações internacionais tendem a promover um modelo abstrato da criança, calcado em preocupações e prioridades que são historicamente circunscritas a países na Europa e na América do Norte. A infância despreocupada - de crianças "inocentes" que dividem seu tempo entre estudo, esportes, família e lazer - teria pouco em comum com a realidade vivida por boa parte da população mundial. Mais ainda, seria uma imagem que pouco contribui para a compreensão do mundo e dos valores dessas "outras" crianças.

Voltando seu olhar para o caso de Recife, Hecht comenta a justaposição de duas noções radicalmente diferentes sobre a infância. Por um lado, haveria "a infância nutrida" (nurtured childhood) das camadas altas:

De forma geral, a "infância nutrida" dos ricos brasileiros tem muito em comum com o ideal da infância entre camadas médias na Europa ou nos Estados Unidos. Só que exagera as formas. As crianças são eximidas da responsabilidade de contribuir para o orçamento familiar, e tampouco espera-se delas que lavem a louça, arrumem suas camas ou limpem seus quartos. Não basta que durmam até tarde durante as férias de verão. Entre os mais ricos, grupos inteiros são enviados à Florida para passar semanas numa espécie de colônia de férias de luxo onde, alojados em hotéis cinco estrelas, passam seus dias comprando joguinhos eletrônicos e fazendo a visita obrigatória a Disney World. (Hecht, 1998, p. 83-84). ${ }^{26}$

Por outro lado, haveria "a infância provedora" (nurturing childhood): a experiência de grande parte das crianças pobres no Brasil que, em vez de viverem a infância como período prolongado de dependência e escolarização, tornam-se desde cedo independentes e muitas vezes ajudam no sustento de seus familiares. $\mathrm{O}$ autor certamente não está querendo promover essa noção

${ }^{26}$ Em outro lugar. Fonseca (no prelo) desenvolve a noção da "criança absoluta" descrita nos seguintes termos: “[...] surgiu no decorrer desse século uma nova idealização da criança que soa curiosamente parecida a certa dimensão da noção pré-moderna. Vemos a criança de novo pintada como 'adulto em miniatura' só que, em vez de negativizada (como incompleto ou incompetente), aparece como uma figura ideal, reflexo da projeção de ideais adultos, e digna de um paraíso sem trabalho, sem disciplina e sem responsabilidade. ['Absoluto' segundo o Novo Dicionário Aurélio, é ‘o que não tem limites, não depende de outrem, não sujeito a condições, superior a todos os outros, que não admite contradições’.].”

Horizontes Antropológicos, Porto Alegre, ano 5, n. 10, p. 83-121, maio 1999 
de infância como um modelo a ser copiado ou expandido. No entanto, o mérito de seu trabalho, como o de outros etnógrafos que descrevem crianças em grupos populares (ver por exemplo Silva e Milita, 1995), é de chamar atenção para a coexistência de diferentes experiências de infância no Brasil e de questionar as abordagens que tendem a ignorar a voz e agency dos que divergem do "ideal".

Não é tarefa fácil viver num contexto com diversidades radicais. Cabe perguntar como membros das camadas altas brasileiras, acostumados a pensar a infância a partir da vida protegida de seus próprios filhos, convivem com a realidade da "infância provedora". Podemos supor que, durante muito tempo, as "novas" sensibilidades familiares, abraçadas pelas famílias da elite, aplicavam-se apenas às crianças oriundas desta classe. Até vinte anos atrás, ainda era possível encontrar empregadas de 13 ou 14 anos arrumando a roupa e cozinhando as refeições dos filhos do patrão. Estes, desonerados das árduas tarefas domésticas, podiam viver plenamente a fase "despreocupada da infância".

Quem sabe, entre as camadas dominantes, uma visão particular do mundo colocava os pobres numa categoria à parte - onde as etapas da vida eram irrelevantes. Dessa forma, os grupos abastados continuavam pagando um salário mínimo aos seus "empregados" (de todas as idades) enquanto recomendavam aos seus próprios filhos recusar trabalho que não tivesse "salário digno". Ocupar empregos "menores", temporários, abaixo da escala de prestígio não era prática adequada à categoria "jovens"; era "adequada", antes, aos membros de determinada classe.

Só recentemente, começa-se a lembrar que a pequena criada, além de ser serviçal e pobre, é criança. Se, antes, uma espécie de racismo velado tinha justificado o tratamento desigual, agora pobres enquanto crianças passam a integrar-se na categoria universal de "humano". Reconhecem-se certas necessidades mínimas para todos os jovens, e a falta dessas "condições mínimas" torna-se intolerável. Mas essa inclusão de um novo grupo no horizonte humanitário não deixa de engendrar paradoxos: por exemplo, quando a criança (ou adolescente) faz 18 anos e muda subitamente de status. (De criança "em perigo" merecendo atenções especiais, passa a ser considerada um adulto "perigoso" contra o qual é preciso se proteger.) Ou quando é preciso achar um culpado pela situação intolerável em que tantas crianças se encontram 
atualmente. Aí, o sacrifício que se oferece para expiar nossa má consciência aparece na figura dos pais desnaturados. A noção de "criança rei”, irrealizável em tantos contextos, engendra seu oposto - a noção da criança martirizada - e, com esta, um novo bode expiatório: os pais algozes.

Trazemos à tona essas reflexões não para recomendar uma reviravolta no nosso tratamento de crianças nem para pleitear um uso discriminatório ou paternalista de princípios básicos de justiça. O movimento pela defesa dos direitos da criança tem surtido efeitos inegavelmente positivos. Existem certas conquistas que são inquestionáveis: a escola universal, a proscrição da exploração de crianças... No entanto, temos que desconfiar do movimento pendular das ideologias que tendem a nos conduzir para exageros do outro extremo ou, pior, em nome de um suposto ideal universal, atropelam a realidade que nos circunda. Diz-se que a legislação brasileira sobre a proteção à infância é de "Primeiro Mundo" - como se isto fosse algo positivo. Sugerimos que o que deveria nos preocupar, antes, é como viabilizar princípios básicos de justiça num contexto em que, manifestamente, a maioria de famílias não vivem em condições de "primeiro mundo". Como dar ouvidos a esses outros, também, enquanto sujeitos de direito?

\section{Indivíduos e individualidade}

Joan Scott (1998), no seu livro Only paradoxes to offer, tenta entender como os autores da revolução francesa - os primeiros a pregar os direitos universais do homem - podiam guilhotinar mulheres que tentavam incluir compatriotas de seu sexo nos termos da declaração. Abraçando a "virada lingüística" nas suas análises históricas, Scott mostra como a discriminação era parte integrante das categorias lógicas dos filósofos de então. O nó do problema se encontrava na justaposição problemática de duas noções: a de indivíduo abstrato - base da unidade humana - e a de individualidade - princípio que realça a diferença entre as pessoas. A tentativa de juntar o "indivíduo" à "individualidade" resultou num "indivíduo abstrato definido por um certo conjunto de traços de tendências psicológicas invariantes" (Scott, 1998, p. 23). Por causa de sua racionalidade e seu sentido moral, o homem branco era, evidentemente, a figura exemplar do individuo humano. "O individuo político 
era reputado ser universal e homem; a mulher não era um indivíduo e isto por dois motivos: ela não era idêntica ao ser humano, e ela era este outro que confirmava a individualidade do indivíduo (masculino)." (Scott, 1998, p. 25-26).

Apesar de Scott centrar suas atenções na luta feminista, é evidente que seu argumento pode ser estendido a todas as categorias que se afastam - por sexo, raça, ou idade... do "ser humano exemplar". Scott não nega que a filosofia das luzes tenha aberto o caminho para a elaboração de uma reflexão sobre a igualdade política, social e econômica. Entretanto, ela mostra como a mesma preocupação pelos direitos do indivíduo abstrato também podia servir para "excluir aquelas pessoas que não possuíam as características exigidas" (Scott, 1998, p. 23-24). Temos aqui as bases filosóficas, presentes na própria acepção dos direitos do homem, para uma classificação dos indivíduos em mais e menos humanos.

Bobbio nos lembra que, depois da Segunda Guerra Mundial, a discussão sobre direitos humanos seguiu dois rumos: ao mesmo tempo em que consolidou-se o aspecto universal destes direitos, tornou-se aparente uma multiplicação dos sujeitos que, em função de suas particularidades, passam a ser vistos como dignos de um tratamento legal específico. Agora vêm à tona critérios de diferenciação (sexo, idade, condição física...) correspondentes a diversos status sociais, "cada um dos quais revela diferenças específicas, que não permitem igual tratamento e igual proteção" (Bobbio, 1992, p. 69). Seguindo neste rumo, temos hoje no Brasil organizações para a promoção dos direitos das categorias mais diversas. Além das mais tradicionais - trabalhando em prol de grupos indígenas, afro-brasileiros, mulheres espancadas e meninos de rua - temos associações promovendo a cidadania de moradores de rua, homossexuais, presos civis, donas de casa... enfim uma série quase infinita de categorias que representam a vasta gama de individualidades da espécie humana. Podemos perguntar se essa multiplicação de categorias resolve o paradoxo levantado por Scott.

Não há dúvida que as atividades desse Terceiro Setor têm surtido efeitos positivos. Gostaríamos de sugerir no entanto que essa proliferação de categorias não deixa de ter seus perigos. Como lembra Scott, a idéia da individualidade é construída por contraste. Há uma tendência de pensar "direitos" e "cidadania" nos mesmos termos: assim, se existem pessoas mais 
merecedoras de direitos, devem existir pessoas menos merecedoras. ${ }^{27}$ É evidente que nenhum militante formula reivindicações nesses termos. Os ganhos de uma categoria deveriam idealmente ser um avanço para o campo inteiro. No entanto, a composição do campo - os pesos relativos atribuídos às diferentes categorias - não é inocente. Quando certas categorias avançam, outras são designadas para ficar para trás. Neste artigo vimos diversos exemplos - do índio em relação ao mendigo, do adolescente em relação ao jovem adulto, dos filhos "abandonados" em relação aos seus pais "negligentes", do homem em relação à mulher. Ao todo, parece que muita gente - uns mais, outros menos marginais - cai pelas fendas da retórica filantrópica. Para essas pessoas, a própria multiplicação de categorias, cunhadas ostensivamente para remediar problemas de pobreza, arrisca servir como um muro de contenção, fazendo mais para excluir do que para incluí-los.

Sugerimos, por fim, que os modelos descontextualizados de direitos humanos - aqueles simulacros do "índio hiper-real", o "quilombola folclorizado" e a "criança absoluta" arriscam não somente reforçar os mecanismos de exclusão mas, pior ainda, negar toda e qualquer apreensão da alteridade. Afinal as individualidades que existem na sociedade contemporânea não são tão facilmente domesticadas; nem tampouco cabem necessariamente nos rótulos das ciências jurídicas. E, no entanto, qualquer política pública voltada para a garantia dos direitos humanos há de levar em consideração a diversidade social. Geertz (neste volume) nos lembra: "O sentimento de ser estrangeiro não começa à beira d'água mas à flor da pele”. O episódio que ele cita do índio bêbado sugere que as diferenças "culturais" mais relevantes no mundo contemporâneo são aquelas que moram na esquina. Não se trata das diferenças receitadas pelos estereótipos do "multiculturalismo enciclopédico" (Turner, 1994) - ou pelo menos não são essas as mais relevantes à discussão sobre direitos humanos. As alteridades que precisam ser enfrentadas são aquelas que menos queremos ver - a dos jovens infratores, por exemplo, ou dos pais dos “abandonados". São "individualidades" que apontam dimensões de nossa realidade que preferiríamos esquecer.

${ }^{27}$ Lembramos do exemplo histórico da distinção feita entre "pobres envergonhados" e "pobres sem vergonha" (ver, entre outros, Donzelot, 1980). 
Afinal, não estamos sugerindo a derrubada das frentes discursivas. Enquanto seres humanos, somos fadados a viver num universo simbólico governado, em grande medida, pelas palavras. Além disso, em muitos casos, essas frentes podem ser postas a serviço da justiça social. Mas, para tanto, é fundamental não ceder à tentação de confundir as palavras com as coisas, de misturar os nomes que nós inventamos com a realidade que os outros vivenciam. Imaginar essas "outras realidades" e explorar o espaço simbólico que nos separa delas seria o ponto de partida de qualquer programa sensato para a promoção dos direitos humanos.

\section{Referências}

ADORNO, S. A experiência precoce da punição. In: MARTINS, J. S. (Org.). O massacre dos inocentes: a criança sem infância no Brasil. São Paulo: Hucitec, 1991.

ALTOÉ, S. Infâncias perdidas: o cotidiano nos internatos-prisão. Rio de Janeiro: Xenon, 1990.

ALVIM, M. R. B.; VALLADARES, L. do P. Infância e sociedade no Brasil: uma análise da literatura. BIB, Rio de Janeiro, n. 26, p. 3-37, 2. semestre 1988.

ALVIM, R. Candelaria 93: um caso limite de violência social. Rio de Janeiro: NEPI/LPSAFCS/UFRJ, 1995.

ARIES, P. História social da criança e da família. São Paulo: Zahar, 1981.

ARRUTI, J. M. A emergência dos "remanescentes": notas para o diálogo entre indígenas e quilombolas. Mana, v. 3, n. 2, p. 7-38, 1997.

BEST, J. Threatened children: rhetoric and concern about child-victims. Chicago: Chicago University Press, 1990.

BOBBIO, N. A era dos direitos. Rio de Janeiro: Campus, 1992. 
BOURDIEU, P. Une classe objet. Actes de la recherche en sciences sociales, n. 17-18, p. 2-5, 1977.

BOURDIEU, P. Le sens pratique. Paris: Editions de Minuit, 1980.

BLUMER, H. Social problems as collective behavior. Social Problems, v. 18, n. 3, p. 298-306, 1971.

CAI-Coordenação do Atendimento ao Infrator. FEBEM-RS. Relatório anual. Porto Alegre, 1995.

CARDARELLO, A. Implantando o Estatuto: um estudo sobre a criança em um sistema próximo ao familiar para crianças institucionalizadas na FEBEM/ RS. 1996. Dissertação (Mestrado em Antropologia Social)-Instituto de Filosofia e Ciências Humanas, Universidade Federal do Rio Grande do Sul, Porto Alegre, 1996.

COMPARATO, F. K. Saudade da "Constituição Cidadã”. Folha de S. Paulo, São Paulo, 3 out. 1998. Especial Constituição 10 Anos, p. 10.

CONRAD, P.; SCHNEIDER, J. W. Deviance and medicalization: from badness to sickness. Philadelphia: Temple University, 1992.

CORRÊA, M. As ilusões da liberdade: a escola Nina Rodrigues e a Antropologia no Brasil. Bragança Paulista: BP: EDSF, 1998.

DAMATTA, R. Relativizando. Rio de Janeiro: Rocco, 1991.

DONZELOT, J. A polícia das famílias. Rio de Janeiro: Graal, 1980.

ESTUDO do atendimento na faixa etária de 0 a 6 anos. Porto Alegre: FEBEM, 1986.

FERNANDES, R. C. Privado porém público: o terceiro setor na América Latina. Rio de Janeiro: Relume Dumará, 1994.

FONSECA, C. Caminhos da adoção. São Paulo: Cortez, 1995. 
FONSECA, C. A modernidade diante de suas próprias ficções: o caso da adoção internacional. Horizontes Antropológicos, Porto Alegre, v. 3, n. 5, p. 204-224, 1997.

FONSECA, C. O abandono da razão: discursos colonizados sobre a família. In: SOUZA, E. A. L. (Org.). Psicanálise e colonização: leituras do sintoma social no Brasil. Porto Alegre: Artes Médicas. No prelo.

FOUCAULT, M. Histoire de la sexualité: I: La volonté de savoir. Paris: Gallimard, 1977.

FREYRE, G. Casa-grande e senzala: formação da família brasileira sob o regime da economia patriarcal. Rio de Janeiro: José Olympio, 1978.

GUIRADO, M. A criança e a FEBEM. São Paulo: Perspectiva, 1980.

HECHT, T. At home in the street: street children of Northeast Brazil. Cambridge: Cambridge University Press, 1998.

KOLLER, S. et al. (Coord.). Perfil do adolescente infrator privado de liberdade interno na FEBEM-RS. Porto Alegre: CEP- Rua: CRIAD/UFRGS: FEBEM-RS, 1996.

MANUAL de instruções para preenchimento da ficha de tabulação referente ao perfil da clientela nos abrigos da FEBEM. Porto Alegre, 1994.

MÉNDEZ, E. G. Adolescentes infratores graves: sistema de justiça e política de atendimento. In: RIZZINI, I. (Org.). A criança no Brasil hoje: desafio para o terceiro milênio. Rio de Janeiro: Universidade de Santa Úrsula, 1993.

MEYER, P. L'enfant et la raison d'état. Paris: Editions du Seuil, 1977.

OLIVEN, R. A parte e o todo: a diversidade cultural no Brasil-Nação. Petrópolis: Vozes, 1992.

PACHECO, J. Muita terra para pouco índio? Uma introdução (crítica) ao indigenismo e à atualização do preconceito. In: SILVA, A. L. da; GRUPIONI, L. D. B. (Org.). A temática indígena na escola. Brasília: MEC: MARI: UNESCO, 1995. 
PASSETTI, E. O menor no Brasil República. In: PRIORE, M. del (Org.). História da criança no Brasil. São Paulo: Contexto, 1991. p. 146-175.

PASSETTI, E. Violentados: crianças, adolescentes e justiça. São Paulo: Editora Imaginário, 1995.

PELLIGRINI, A. et al. Possibilidades de um perfil do adolescente autor de ato infracional. Porto Alegre: FEBEM-RS, 1996.

RAMOS, A. A hall of mirroirs. Critique of Anthropology, v. 11, n. 2, p. 155$169,1991$.

RIBEIRO, F. Conselheiro tutelar: um agente social em construção. In: COLOMBO, N. F.; BIZ, O. (Org.). Integração, cidadania, espaços. Porto Alegre: EDIPUCRS, 1998.

RIZZINI, I. et al. O que as pesquisas revelam sobre a situação da infância na década de 80?: levantamento da produção científica. Rio de Janeiro: CESPI, 1992. Relatório de pesquisa.

ROSA, R. A temporalidade kaingaing na espiritualidade do combate. 1998. Dissertação (Mestrado em Antropologia Social)-Instituto de Filosofia e Ciências Humanas, Universidade Federal do Rio Grande do Sul, Porto Alegre, 1998.

ROSEMBERG, F. O discurso sobre criança de rua na década de 80. Cadernos de Pesquisa, n. 87, p. 71-81, 1993.

SCOTT, J. W. La citoyenne paradoxale: les féministes fançaises et les droits de l'homme. Paris: Albin Michel, 1998.

SILVA, H. R. S.; MILITA, C. Vozes do meio-fio. Rio de Janeiro: Relumé Dumará, 1995. 
TURNER, T. Anthropology and multiculturalismi what is anthropology that multiculturalists should be mindful of it?. In: GOLDBERG, D. T. (Ed.). Multiculturalism: a critical reader. Oxford: Basil Blackwell, 1994.

VIANNA, L. W. Poder Judiciário, "positivação" do direito natural e história. Estudos Históricos, v. 9, n. 18, p. 257-424, 1996.

VIOLANTE, M. L. O dilema do decente malandro. São Paulo: Cortez, 1985.

VOLPI, M. O adolescente e o ato infracional. São Paulo: Cortez, 1997. 